14. Добровольская Т.Г., Головченко А.В., Лы- териальных и актиномицетных комплексов торфясак Л.В., Зенова Г.М. Физикохимия и биология тор- ных почв. Томск: Издательство Томского ГПУ, 2010. фа. Методы оценки численности и разнообразия бак- 97 с.

\title{
ECOLOGICAL STATUS ASSESSMENT OF MICROBIC POPULATION FROM CESPITOSE-PODSOLIC SOIL BASIC SAPROTHROPHIC MICROBIC POOL AT THE INZENSKY FIELD DIATOMITE BIOCHEMICAL DESTRUCTION
}

(C) 2018

Kozlov Andrey Vladimirovich, candidate of biological sciences, associate professor of Ecological Education and Rational Environmental Management Department Minin Nizhny Novgorod State Pedagogical University (Nizhny Novgorod, Russian Federation)

Kulikova Alevtina Hristoforovna, doctor of agricultural sciences, head of Soil Science, Agrochemistry and Agroecology Department Ulyanovsk State Agrarian University named after P.A. Stolypin (Ulyanovsk, Russian Federation)

Uromova Irina Pavlovna, doctor of agricultural sciences, professor of Biology, Chemistry and Biological and Chemical Education Department Minin Nizhny Novgorod State Pedagogical University (Nizhny Novgorod, Russian Federation)

Abstract. The following paper considers reaction of the saprothrophic and ammoniphycal microbic populations, allocated from the cespitose-podsolic sandy loamy soil of the Nizhny Novgorod Region, to the Inzensky field diatomite substance. On this basis the ecological status of these microorganisms in relation to the studied high-siliceous breed is estimated subsequently. 7-day accumulative cultures of general saprothrophic and ammoniphycal bacteria were used in the study. Living cells were emitted from the cespitose and podsolic soil selected from the Borsky district field «Elitkhoz» by the standard rules in microbiological biotechnology. The result of the research was 30-day dynamics of the breed culture system regarding change of living cells number and proteolytic enzymatic activity of bacterial suspension at biochemical degradation of diatomite substance. The described reaction of microbic complexes in the form of positive dynamics of number and protease activity demonstrates direct destruction interaction of bacterial cultures with diatomite breed that, in turn, can assume their active reaction with this breed and organic substance of the soil with the subsequent release in soil solution of various nutritious elements and in general - stabilization of bacterial L-strategists in the general ecological status of soil microbiocenosis.

Keywords: diatomite breed of Inzensky field; cespitose and podsolic sandy loam soil; bacterial L-strategists; general soil dwelling saprothrophic; ammoniphycal; breed culture system; viability of bacterial culture; proteolytic enzymatic activity; stability of soil microbiocenosis ecological status.

\section{НОВЫЙ МЕТОДИЧЕСКИЙ ПОДХОД К ОЦЕНКЕ МЕХАНИЧЕСКОЙ УСТОЙЧИВОСТИ ЗЕЛЁНЫХ НАСАЖДЕНИЙ В ГОРОДСКОЙ СРЕДЕ}

(C) 2018

Корниенко Владимир Олегович, старший преподаватель кафедры биофизики

Донеикий национальный университет (г. Донеик, Донецкая Народная Республика)

Приходько Светлана Анатольевна, кандидат биологических наук, старший научный сотрудник, директор Донецкий ботанический сад (2. Донецк, Донецкая Народная Республика)

Аннотация. Наибольший прессинг негативных экзогенных факторов испытывают деревья, произрастающие в городской среде, и как следствие многие породы древесных растений достигают критического возраста и являются аварийными. Комплексный подход к оценке состояния древесных насаждений в условиях техногенной нагрузки с использованием визуальных, инструментальных, биомеханических и других методов позволит своевременно и достоверно выявлять потенциально аварийные растения. Для достижения этой цели нами была разработан новый методический подход к определению степени аварийности деревьев в населённых пунктах на основе учёта оценки механической устойчивости древесных растений и данных современных инструментальных методов исследований, которые могут быть использованы службами, осуществляющими мониторинг состояния и уход за зелёными насаждениями. Основными параметрами служат: возраст, диаметр основания, диаметр на высоте, обхват ствола у основания, обхват ствола на высоте 1,3 м, высота дерева, угол наклона ствола, балл жизненного состояния по Савельевой, морфологические повреждения ствола, описание архитектоники кроны, наличие морфогенетических и экзогенных повреждений листовой пластинки, заселённость ствола вредителями, наличие дупел, ветровая особенность и нагруженность данного участка местности, режим посещения территории (рекреационная нагрузка), направление возможного падения, длина участка здоровой древесины на керне, процент ядровой гнили, модуль упругости древесины, плотность древесины, отношение биомассы к критической массе, механическая устойчивость к статическим и динамическим нагрузкам согласно расчётам по биомеханике. В статье на примере модельного дерева платана кленолистного продемонстрирована возможность использования такого подхода в практической работе.

Ключевые слова: аварийные деревья; механическая устойчивость; визуальная диагностика; модуль упругости; инструментальная диагностика; шкала аварийности; критическая нагрузка; антропогенное влияние; приростной бурав; Platanus acerifolia (Aiton) Willd.; статическая нагрузка; динамический фактор; ветер. 


\section{Введение}

Древесные насаждения являются важнейшей составляющей современных городов. Они участвуют в поддержании жизнедеятельности и формировании облика города, очищении воздушной среды, улучшении микроклимата, создании комфортных условий жизни горожан. Рекреационная, эстетическая, санитарно-гигиеническая, санационная и другие экологические и средообразующие функции зелёных насаждений определяются свойствами самих растений и их сообществ, среди которых: поглощение углекислого газа и выделение кислорода в ходе фотосинтеза; испарение влаги при транспирации, в результате которой регулируется водный и температурный режимы; выделение фитонцидов - биологически активных веществ, которые подавляют или полностью прекращают рост и развитие болезнетворных микроорганизмов; фиксирование пылевых частиц на поверхности листьев и поглощение ими газов; формирование электрического поля и образование отрицательных аэроионов кислорода; изменение температуры и влажности воздуха и почвы под пологом насаждений; поглощение энергии ветра, вибраций почвы и акустического шума, накопление снега; создание среды обитания для различных групп организмов; положительное влияние на эмоциональное состояние человека.

Эффективное использование и полноценное выполнение функций зелёных насаждений возможно лишь в случае, если составляющие их растения обладают высокой жизнеспособностью, а условия произрастания в городской среде соответствуют их биологическим потребностям и экологическим особенностям. В промышленных городах древесная растительность подвергается значительной техногенной нагрузке: запыление, загазованность, загрязнение и засоление почв, грунтовых и почвенных вод. В результате ослабленные деревья теряют жизнеспособность, постепенно усыхают и отмирают значительно раньше, чем в естественной среде обитания. Вовремя не убранные повреждённые растения или их части могут обламываться под действием собственного веса или ветровых нагрузок, становятся опасными для здоровья и жизни горожан, приносят экономические убытки.

В Донецке изучение этих биолого-экологических особенностей растений является одной из основных научных задач. За десятки лет работы Донецкого ботанического сада и Донецкого национального университета его учёными были опубликованы не только научные статьи и монографии, но и ряд практических рекомендаций для предприятий зелёного строительства [1-22].

Цель работы - разработать новый методический подход к определению степени аварийности деревьев в населённых пунктах на основе учёта оценки механической устойчивости древесных растений и данных современных инструментальных методов ис- следований, которые могут быть использованы службами, осуществляющими мониторинг состояния и уход за зелёными насаждениями.

Задачи: 1) разработать алгоритм нового методического подхода определения степени аварийности деревьев; 2) провести диагностику состояния деревьев основных пород, используемых в озеленении города Донецка, с применением комплекса методик, включающих классические и современные методы оценки состояния аварийности древесных растений в городской среде; 3) обосновать необходимость внедрения новых методов контроля состояния аварийности деревьев в городских условиях на примере модельного дерева; 4) разработать шкалу и бланк оценки аварийности дерева в условиях города.

\section{Материал и методы исследований}

В настоящее время практикуется использование современной системы контроля состояния зелёных насаждений, которая предусматривает комплекс организационных мероприятий, обеспечивающий эффективный контроль, прогноз состояния зелёных насаждений с учётом экологической ситуации региона.

При оценке древесных насаждений нами были использованы следующие методы:

1. Визуальный (осмотр дерева с земли, осмотр дерева с подъёмом на ствол, осмотр местности);

2. Ретроспективный (изучение исполнительной и проектной документации по строительным и ландшафтным работам, изучение ветровой особенности и нагруженности данного участка местности, выявление предыдущих случаев падения деревьев);

3. Инструментальный:

3.1. Инструментальный инвазивный контроль:

а) взятие керна прирастным буром (Бурав Пресслера);

3.2. Прямое испытание биомеханических свойств дерева (прочность и устойчивость) - «Pulling test» (помимо инструментального, этот метод имеет наиболее значимую составляющую числового моделирования).

Диагностика при помощчи прирастного бурава. Согласно приложению 4а к действующим «Правилам создания, содержания и охраны зелёных насаждений города Москвы» [23] с помощью кернов, извлечённых буром из дерева, можно установить поражённость гнилью. Процент здоровой и гнилой древесины определяется по формуле:

$$
K=\frac{r-l}{r} \cdot 100 \%
$$

где $\mathrm{r}$ - радиус ствола в месте отбора керна; $l$ - длина участка здоровой древесины на керне.

Одним из вариантов интерпретации данных, полученных при проведении исследований с помощью бура, является шкала, представленная в табл. 1.

Таблица 1 - Шкала оценивания результатов измерений для извлечённого керна

\begin{tabular}{|c|c|c|l|}
\hline Класс & Доля ядровой гнили, \% & Аварийность & \multicolumn{1}{|c|}{ Предпринимаемые меры } \\
\hline 1 & $\geq 80$ & очень высокая & необходимо срочно удалить дерево \\
\hline 2 & $40-79$ & высокая & $\begin{array}{l}\text { если такое дерево расположено рядом с жилыми по- } \\
\text { стройками, социально-значимыми объектами инфра- } \\
\text { структуры, то его рекомендуется удалить }\end{array}$ \\
\hline 3 & $5-39$ & низкая & $\begin{array}{l}\text { рекомендуется отслеживать развитие гнили у такого рас- } \\
\text { тения, провести обязательное лечение заболевания, воз- } \\
\text { можно, снизить парусность кроны за счёт кронирования }\end{array}$ \\
\hline
\end{tabular}


Для оценки прочности и механической устойчивости древесных растений в урбанизированных городах использовали следующие параметры:

$\mathrm{P}_{\mathrm{cr}}$ и $\mathrm{m}_{\mathrm{cr}}$ - предельно допустимая нагрузка и масса, при действии которых ствол начинает деформироваться или обламывается:

$$
\begin{gathered}
P C r=\frac{\pi^{2} E I}{2 l^{2}} \\
m c r=\frac{P C r}{g}
\end{gathered}
$$

где $I$ - момент инерции сечения, $l$ - длина ствола, $\mathrm{g}$ ускорение силы тяжести.

$\mathrm{H}_{\mathrm{cr}}$ - критическая высота ствола, при достижении которой действие собственного веса привело бы к необратимой деформации или облому [24]:

$$
H c r=C \cdot \frac{E^{1 / 3}}{\rho} \cdot d^{2 / 3}
$$

где $C$ - коэффициент соотношения массы кроны и ствола, $d$ - диаметр основания ствола.

Критическая длина ствола или побега, при достижении которой действие собственного веса или минимальной нагрузки привело бы к деформации или крушению:

$$
\begin{gathered}
\text { Для цилиндра Lcrit }=0.79 \cdot\left(\frac{E}{\rho \cdot g}\right)^{1 / 3} \cdot d^{2 / 3} \\
\text { Для конуса Lcrit }=1.25 \cdot \frac{E}{\rho \cdot g}^{1 / 3} \cdot d^{2 / 3}
\end{gathered}
$$

RRB - относительное сопротивление изгибу [25]:

$$
R R B=\frac{r^{2} E}{4 \rho}
$$

где $\mathrm{r}$ - радиус основания ствола, $\mathrm{E}$ - модуль упругости, $\rho$ - плотность древесины.

Модуль упругости древесных волокон определяется по величине изгиба цилиндра обрезанной ветви, горизонтально защемлённой в тисках, в ответ на приложение силы $F$ на её свободном конце по формуле [10]:

$$
E=\frac{64 C l^{3}}{3 \pi d^{4}}
$$

где $C$ - жёсткость цилиндра, $l$ - его длина, $d$ - диаметр.

Жёсткость ствола, побега (C) рассчитывается как:

$$
C=\frac{m g}{x}
$$

где $m$ - масса приложенного груза, $g$ - ускорение силы тяжести, $x$ - смещение свободного конца цилиндра.

В частности, способность сопротивляться изгибу определяется как произведение модуля упругости $(M O E)$ и второго момента сечения (I) ствола (11). Аналогичным образом, способность к сопротивлению скручивания определяется как произведение модуля сдвига $G$ и полярного момент инерции площади $J$, который называется жёсткостью при кручении [26]:

$$
\text { Сопротивление изгибу }=E I
$$

Сопротивление скручиванию $=G J$

$$
\text { где } I=\frac{\pi r^{4}}{4}, I=\frac{\pi r^{4}}{2}, \mathrm{r}-\text { радиус. }
$$

Высоту дерева измеряли с помощью электронного высотомера - HEC Haglof, угол отхождения от ствола в программе - AxioVisionRel. 4.8, взятие кернов осуществлялось с помощью приростного бурава Haglof (Швеция).

\section{Результаты исследований и их обсуждение}

В качестве объекта исследования были выбраны деревья основных пород, используемых в озеленении города Донецка (Betula pendula Roth, Quercus robur L., Quercus rubra L., Populus alba L., Populus nigra L., Populus boleana Laiche, Acer platanoides L., Acer negundo L., Fraxinus excelsior L., Robinia pseudoacacia L., Gleditsia triacanthos L. и др.). Были охвачены различные места произрастания этих деревьев на территории города (насаждения вдоль автомагистралей, селитебная и парковая зоны, санитарно-защитные зоны промышленных предприятий и др.). Учитывались следующие показатели: критический возраст в условиях региона; угол наклона ствола от вертикали (оценивается по трём градациям: а) 10\% и менее, б) 11-40\%, в) более $40 \%$.); наличие морозобоин, дупел, развилок, раковых повреждений, плодовых тел дереворазрушающих грибов, видимых повреждений корневой системы в результате строительных работ; архитектоника кроны (развитость кроны, асимметрия, сомкнутость, состояние листовых пластинок, усыхание ветвей); заселённость ствола вредителями; процент ядровой гнили (оценивается по трём градациям: а) $\geq 80$, б) 40-79, в) 5-39); режим посещения территории (рекреационная нагрузка), направление возможного падения в сторону возможного скопления людей (рассматривается при выявлении скрытых гнилей); отношение диаметра к длине ствола; биомассы надземной части к критической массе с учётом угла наклона и ядровой гнили; механическая устойчивость к статическим нагрузкам; механическая устойчивость к динамическим нагрузкам.

На основе анализа массивов экспериментальных данных состояния пород деревьев, был выработан новый методический подход к оценке состояния зелёных насаждений. Это подход, с одной стороны, является высоко информативным и научным, с другой - упрощает работу специалистов благодаря конкретно заданным параметрам диагностики. Преимуществом данного подхода также является его дешевизна. Конкретный пример использования разработанного подхода диагностики состояния зелёных насаждений рассмотрен на модельном дереве платана кленолистного, произрастающего на территории Донецкого ботанического сада.

Визуальный осмотр. При наличии ветра наблюдается незначительное по амплитуде раскачивание ствола; присутствуют усыхающие скелетные ветви в кроне, ствол повреждён морозобоинами, имеется дупло, от которого распространяется гниль; угол наклона ствола от вертикали 20\%; крона асимметрична.

Инструментальный инвазивнылй контроль (взятие керна прирастным буром). Известно, что резкое 
Корниенко В.О., Приходько С.А.

снижение устойчивости дерева происходит, когда толщина стенки живой древесины составляет менее $15 \%$ от радиуса ствола. Для исследуемого дерева процентное соотношение ядровой гнили к живой составляло 58\% (2 класс, см. табл. 1). За последние 10 лет (2007-2017) прирост варьировал от 0,3 до 0,5 см, что может говорить о том, что ранняя диагностика аварийности с помощью инструментальных методов могла бы устранить скрытую гниль в начале её распространения и на сегодняшний день аварийность дерева была бы минимальная.

Исследование ветровой устойчивости. Дерево расположено в слабо продуваемом месте, однако с учётом изменяющегося климата и при появлении в зимний период сильных порывистых ветров аварийность растения высока. К статическим нагрузкам растение устойчиво. Также необходимо учесть, что растение произрастает вблизи тепличного комплекca, запасного выхода из главного корпуса и эта территория входит в экскурсионный маршрут.

Биомеханические исследования. Модуль упругости платана составил 4,3 ГН/ $\mathrm{M}^{2}$, что является высоким показателем для степной зоны. Отношение биомассы к критической массе надземной части находится в пределах нормы, однако, учитывая процент гнили $(58 \%)$, следует снизить высоту и массу кроны для обеспечения механической устойчивости всего дерева.

После всех проведённых исследований и расчётов составляется общая таблица, согласно разработанному нами бланку, для оценки механической устойчивости дерева (табл. 2). Данный бланк можно использовать в полевых условиях и на его основе составлять «Экспертное заключение» об аварийности дерева. Оно всегда будет носить вероятностный характер вне зависимости от применяемых методов. Наличие инструментального оборудования позволяет лишь повысить верность оценки.

Для оценки аварийности мы предлагаем 10балльную шкалу (тестовую, полевую) со следующими признаками:

1. Критический возраст в условиях региона (если критический -16 , если нет +16$)$.

2. Угол наклона ствола от вертикали (оценивается по трём градациям: а) 10\% и менее, б) 11-40\%, в) более $40 \%$ ).

3. Наличие морозобоин, дупел, развилок, раковых повреждений, плодовых тел дереворазрушающих грибов, видимых повреждений корневой системы в результате строительных работ (при наличии -1б).

4. Архитектоника кроны (развитость кроны, асимметрия, сомкнутость, поврежденность листовых пластинок, усыхание ветвей).

5. Заселённость ствола вредителями (при наличии $-16)$.

6. Процент ядровой гнили (оценивается по трём градациям: а) $\geq 80$, б) 40-79, в) 5-39).

7. Режим посещения территории (рекреациионная нагрузка), направление возможного падения в сторону возможного скопления людей (рассматривается при выявлении скрытых гнилей).

8. Отношение диаметра к длине ствола; биомассы надземной части к критической массе с учётом угла наклона и ядровой гнили.

9. Механическая устойчивость к статическим нагрузкам.

10. Механическая устойчивость к динамическим нагрузкам. таблица 2 - Бланк оценки механической устойчивости древесных растений на примере платана кленолистного

\begin{tabular}{|c|c|}
\hline $\begin{array}{l}\text { Параметр, } \\
\text { ед. измерения }\end{array}$ & Показатель \\
\hline Вид & $\begin{array}{c}\text { Платан клено- } \\
\text { листный } \\
\text { [Platanus acerifolia } \\
\text { (Aiton) Willd.] }\end{array}$ \\
\hline Возраст, лет* & 45 \\
\hline Диаметр основания, $\mathrm{d}_{\text {осн }}$, м & 0,615 \\
\hline Диаметр на высоте 1,3 м, $\mathrm{d}_{\mathrm{bh}}, \mathrm{m}$ & 0,535 \\
\hline $\begin{array}{l}\text { Обхват ствола у основания } \\
\text { C }_{\text {осн }}, \mathrm{M}\end{array}$ & 1,9 \\
\hline $\begin{array}{l}\text { Обхват ствола на высоте } 1,3 \text { м, } \\
\text { C }_{\text {bh }}, \mathrm{M}\end{array}$ & 1,7 \\
\hline Высота дерева, Н, м & $19,9 \pm 0,1$ \\
\hline Угол наклона ствола, град & 74 \\
\hline $\begin{array}{l}\text { Балл жизненного состояния } \\
\text { по Савельевой }\end{array}$ & 5 \\
\hline $\begin{array}{l}\text { Морфологические } \\
\text { повреждения ствола }\end{array}$ & $\begin{array}{l}\text { морозобоины, } \\
\text { дупло }\end{array}$ \\
\hline $\begin{array}{l}\text { Описание архитектоники кро- } \\
\text { ны }\end{array}$ & $\begin{array}{c}\text { наблюдается } \\
\text { асимметрия, не- } \\
\text { равномерное рас- } \\
\text { пределение массы }\end{array}$ \\
\hline $\begin{array}{l}\text { Наличие морфогенетических } \\
\text { и экзогенных повреждений } \\
\text { листовой пластинки, } \pm\end{array}$ & + \\
\hline $\begin{array}{l}\text { Заселённость ствола } \\
\text { вредителями, } \pm\end{array}$ & + \\
\hline Наличие дупел, \pm & + \\
\hline $\begin{array}{l}\text { Ветровая особенность } \\
\text { и нагруженность } \\
\text { данного участка местности }\end{array}$ & $\begin{array}{c}\text { дерево защищено } \\
\text { от ветра, находит- } \\
\text { ся в слабо проду- } \\
\text { ваемом месте }\end{array}$ \\
\hline $\begin{array}{l}\text { Режим посещения территории } \\
(\text { рекреационная нагрузка) }\end{array}$ & высокая \\
\hline $\begin{array}{l}\text { Направление возможного } \\
\text { падения }\end{array}$ & $\begin{array}{l}\text { в сторону теплич- } \\
\text { ного комплекса, } \\
\text { расстояние до це- } \\
\text { ли } 16-17 \text { м }\end{array}$ \\
\hline $\begin{array}{l}\text { Диаметр ствола } \\
\text { в месте забора керна, м }\end{array}$ & 0,27 \\
\hline $\begin{array}{l}\text { Длина участка здоровой } \\
\text { древесины на керне, } l, \text { см}^{*}\end{array}$ & 9,5 \\
\hline Процент ядровой гнили, \%* & 58 \\
\hline $\begin{array}{l}\text { Модуль упругости древесины, } \\
\text { Е, ГН/м }{ }^{2 *}\end{array}$ & 4,3 \\
\hline Плотность древесины, $\rho к г / \mathrm{M}^{3}$ & 1030 \\
\hline Отношение $\mathrm{Bm} / \mathrm{m}_{\mathrm{cr}}{ }^{*}$ & 0,2 \\
\hline $\begin{array}{l}\text { Механическая устойчивость } \\
\text { к статическим/динамическим } \\
\text { нагрузкам согласно расчётам } \\
\text { по биомеханике, } \pm^{*}\end{array}$ & $\begin{array}{l}\text { к статическим + } \\
\text { к динамическим - }\end{array}$ \\
\hline Степень опасности** & высокая \\
\hline
\end{tabular}

Примечание. * - отмечены параметры, измерить которые возможно только современными методами исследования; ** - оценка степени опасности дерева производится путём сложения с различными весовыми коэффициентами, числового выражения различных влияющих факторов. 
Для исследуемого платана кленолистного оценка составила 3б, что говорит о его высокой аварийности. Однако при проведении мероприятий, таких как обеззараживание, от вредителей, кронирование (снижение массы, парусности) и создание недоступности к проникновению внутрь ствола вредителей, влаги и т.д., его аварийность снизится. Разработанная шкала оценки аварийности деревьев в городской среде представлена в таблице 3 .

Таблица 3 - Шкала оценки аварийности древесных растений

\begin{tabular}{|c|l|}
\hline Балл & \multicolumn{1}{|c|}{ Степень аварийности } \\
\hline $0-2$ & $\begin{array}{l}\text { Очень высокая - полная потеря прочности } \\
(\text { устойчивости) возможно падение (обруше- } \\
\text { не) дерева в ближайшее время. }\end{array}$ \\
\hline $3-4$ & $\begin{array}{l}\text { Высокая - повышенная ветровальность де- } \\
\text { рева, возможно падение при сильном ветре } \\
\text { или при налипании снега, наледи. }\end{array}$ \\
\hline $5-6$ & $\begin{array}{l}\text { Средняя - в результате развития гнилевых } \\
\text { процессов в течение нескольких лет вероят- } \\
\text { ность падения дерева существенно возрас- } \\
\text { тёт. }\end{array}$ \\
\hline $7-8$ & $\begin{array}{l}\text { Низкая - дерево устойчиво при нормальных } \\
\text { погодных условиях и средних значениях вет- } \\
\text { ровых нагрузок характерных для региона. }\end{array}$ \\
\hline $9-10$ & $\begin{array}{l}\text { Без замечаний - вероятность падения или } \\
\text { переламывания ствола при экстремальных } \\
\text { погодных явлениях минимальна. }\end{array}$ \\
\hline
\end{tabular}

\section{Выводы}

Для достоверной оценки зелёных насаждений в городских условиях необходимо применять комплексный подход, включающий использование визуального и инструментального методов, учёта биомеханических параметров устойчивости растений в условиях техногенной нагрузки, эдафо-климатических условий.

В зоне повышенной плотности населения и автотранспорта необходимо использовать максимальное количество методик для вынесения экспертного заключения с долей вероятности $>80 \%$. Без инструментальных методов оценки деревьев, экспертное заключение не может быть достоверным и носит только рекомендательный характер.

C помощью комплексного подхода при диагностике платана кленолистного установлен достоверный уровень его аварийности.

Разработаны методический алгоритм, шкала и бланк оценки аварийности дерева в условиях города, которые могут быть использованы в практической работе службами, осуществляющими мониторинг состояния и уход за зелёными насаждениями.

Отдельную благодарность сотрудники ГУ «Донеикий ботанический сад» и ГОУ ВПО «Донеиякий национальный университет» выражают руководителю региональной группь общественного мониторинга ОНФ по проблемам экологии и защиты леса в Московской области Хльнову Антону Юрьевичу за помощь и предоставление инструментального оборудования для выполнения исследований.

\section{Список литературы:}

1. Кондратюк Е.Н., Поляков А.К. Пути ускоренной интродукции видов сосны на Донбассе // Бюл. Гл. ботан. сада СССР. 1982. Вып. 124. С. 8-13.
2. Кондратюк Е.Н., Поляков А.К., Рубцов А.Ф. Интродукция хвойных на юго-восток Украины // 7 делегат. съезда Всесоюз. ботан. общ-ва: тез. докл. Л.: Наука, 1983. С. 394.

3. Поляков А.К., Малюгин И.Е., Тарабрин В.П. Древесные насаждения в оптимизации техногенной и рекреационной среды Приазовья. К.: Наук. думка, 1992. $170 \mathrm{c}$.

4. Коршиков И.И., Терлыга Н.С., Бычков С.А. Популяционно-генетические проблемы дендро-техногенной интродукции (на примере сосны крымской). Донецк: Лебедь, 2002. 328 с.

5. Поляков А.К., Суслова Е.П. Состояние древесных растений в условиях техногенного воздействия и принципы формирования устойчивых насаждений // Промышленная ботаника. 2004. Вып. 4. С. 72-79.

6. Коршиков И.И. Устойчивость растений к техногенным загрязнителям окружающей среды // Промышленная ботаника. 2004. Вып. 4. С. 46-58.

7. Поляков А.К., Суслова Е.П., Терещенко С.И. Видовой состав городских насаждений юго-востока Украины и перспективы его обогащения // 12 з'їзд Укр. ботан. т-ва: матер. (м. Одеса, 15-18 травня 2006 р.). Одеса, 2006. С. 358.

8. Корниенко В.О., Роменский М.В., Нецветов М.В. Вибрации растений, индуцированные естественными источниками и автомобильным транспортом // БФФХ-2008: мат-лы 4 всеукраинской науч.-технич. конф. Севастополь: СевНТУ, 2008. С. 155-157.

9. Нецветов М.В., Хиженков П.К., Суслова Е.П. Введение в вибрационную экологию. Донецк: Вебер, 2009. 165 c.

10. Нецветов М.В., Суслова Е.П. Механическая устойчивость деревьев и кустарников к вибрационным нагрузкам // Промышленная ботаника. 2009. Вып. 9. С. 60-67.

11. Поляков А.К. Интродукция древесных растений в условиях техногенной среды. Донецк: Ноулидж, 2009. 268 с.

12. Корнієнко В.О., Нецветов М.В., Нікуліна В. Дослідження стійкості дерев до вібрацій // Вісник Львів. ун-ту Серія фіз. 2009. Вип. 44. С. 185-193.

13. Поляков А.К., Суслова Е.П. Динамика производительности древостоев перспективных интродуцированных древесных пород // Промышленная ботаника. 2010. Вып. 10. С. 49-53.

14. Поляков А.К., Суслова Е.П., Нецветов М.В., Дацько А.М., Козленко Д.А., Лихацкая Е.Н. Биоэкологические особенности раритетных видов древеснокустарниковых растений ех situ // Промышленная ботаника. 2010. Вып. 10. С. 67-72.

15. Нецветов М.В., Корниенко В.О. Влияние листьев на динамические характеристики Acer saccharinum L. и A. ibericum Bieb. // Проблеми екології та охорони природи техногенного регіону. 2010. № 1 (10). С. 246-251.

16. Абоимова А.Н., Поляков А.К. Рост и развитие Juglans nigra L. на юго-востоке Украины // Промышленная ботаника. 2012. Вып. 12. С. 283-287.

17. Суслова Е.П., Поляков А.К., Нецветов М.В., Дацько А.М., Лихацкая Е.Н. Жизнеспособность древесных растений в городских уличных насаждениях на юго-востоке Украины // Промышленная ботаника. 2012. Вып. 12. С. 12-19. 
18. Корниенко В.О., Нецветов М.В. Влияние отрицательных температур на механическую устойчивость дуба красного (Quercus rubra L.) // Промышленная ботаника. 2013. Вып. 13. С. 180-186.

19. Корниенко В.О., Нецветов М.В. Криоскопия влаги и температурная зависимость модуля упругости древесины // Вісті Біосферного заповідника «Асканія-Нова». 2014. Т. 16. С. 88-94.

20. Корниенко В.О., Такташов Р.Б., Нецветов М.В. Сильватизирующий эффект и динамика насаждений Ailanthus altissima (Mill.) Swingle на угольных отвалах // Промышленная ботаника. 2014. Вып. 14. С. $69-$ 76.

21. Корниенко B.O. Influence of cyclic freezing and thawing upon the mechanical stability of pedunculate oak Quercus robur L. // 5 съезд биофизиков: матер. междунар. конф. Ростов-на-Дону, 2015. С. 360.
22. Netsvetov M., Sergeyev M., Nikulina V., Korniyenko V., Prokopuk Yu. The climate to growth relationships of pedunculate oak in steppe // Dendrochronologia. 2017. № 44. P. 31-38.

23. Правила создания, содержания и охраны зеленых насаждений города Москвы. М.: Департамент природопользования и охраны окружающей среды, 2012. $138 \mathrm{c}$.

24. Niklas K.J. Plant biomechanics: an engineering approach to plant form and function. Chicago: University of Chicago Press. 1992. 622 p.

25. Niklas K.J. Worldwide correlations of mechanical properties and green wood density // American Journal of Botany. 2010. Vol. 97 (10). P. 1587-1594.

26. Tropical Tree Physiology: Adaptations and Responses in a Changing Environment / Ed. Goldstein G., Santiago L.S. 2016. Vol 6. 467 p.

\section{A NEW METHODOLOGICAL APPROACH TO EVALUATION OF MECHANICAL RESISTANCE OF GREEN PLANTINGS IN URBAN ENVIRONMENTS}

(C) 2018

Kornienko Vladimir Olegovich, senior lecturer of Biophysics Department

Donetsk National University (Donetsk, Donetsk People's Republic)

Prikhodko Svetlana Anatolyevna, candidate of biological sciences, senior researcher, director Donetsk Botanical Garden (Donetsk, Donetsk People's Republic)

Abstract. The trees growing in urban environments are exposed to the highest pressure of negative exogenous factors and, consequently, many tree species come to the critical age and become hazardous. A complex approach to evaluate the condition of green plantings under the technogenous load using visual, instrumental, biomechanical etc. methods allows timely and reliable identification of hazardous trees. For this purpose, we developed a new methodology of determining the hazardous degree of trees in residential areas. This method is based on the accounts of tree mechanical hardiness evaluation and up-to-date instrumental research data to be used by municipal services employed in plantings monitoring and care. The main parameters are: age, diameter of the base, diameter at height, trunk girth at the base, trunk girth at a height of $1,3 \mathrm{~m}$, the height of the tree, the angle of inclination of the trunk, the vital status score for Saveleva, morphological damage to the trunk, the description of the crown architectonics, the presence of morphogenetic and exogenous damage to the leaf blade, the population of the trunk pests, the presence of hollows, the wind feature and the loading of this site, the mode of visiting the territory (recreational load), the direction of possible fall, percentage of sound rot, modulus of elasticity of wood, density of wood, the ratio of biomass to critical mass, mechanical resistance to static and dynamic loads according to calculations on biomechanics. In the case study of a model tree (London plane) the applicability of this approach to landscaping practices is shown.

Keywords: hazardous trees; mechanical stability; visual diagnostics; modulus of elasticity (MOE); instrumental diagnostics; scale of accident; critical load; anthropogenic influence; age drill; Platanus acerifolia (Aiton) Willd.; static load; dynamic factor; wind.

\section{ОЦЕНКА ИЗМЕНЕНИЯ АКТУАЛЬНОЙ И ОБМЕННОЙ КИСЛОТНОСТИ ДЕРНОВО-ПОДЗОЛИСТОЙ ЛЕГКОСУГЛИНИСТОЙ ПОЧВЫ ПРИ ПРИМЕНЕНИИ ЦЕОЛИТА ХОТЫНЕЦКОГО МЕСТОРОЖДЕНИЯ}

Куликова Алевтина Христофоровна, доктор сельскохозяйственных наук, заведующий кафедрой почвоведения, агрохимии и агроэкологии Ульяновский государственный аграрный университет имени П.А. Стольпина (2. Ульяновск, Российская Федерация)

Козлов Андрей Владимирович, кандидат биологических наук, доцент кафедры экологического образования и рационального природопользования Уромова Ирина Павловна, доктор сельскохозяйственных наук, профессор кафедры биологии, химии и биолого-химического образования Нижегородский государственный педагогический университет имени Козьмы Минина (2. Нижний Новгород, Российская Федерация)

Аннотация. В данной статье рассматривается степень влияния цеолитовой породы Хотынецкого месторождения на показатели актуальной и обменной кислотности дерново-подзолистой легкосуглинистой почвы Нижегородской области. Трехлетний эксперимент, представляя собой микрополевой опыт, был заложен в 